\title{
Elipsis (al-Hadhf) dalam al-Quran sebagai Satu Petunjuk Ketinggian Bahasa Arab Kalamullah \\ Ellipsis (al-Hadhf) in the Quran as a Mark of the Arabic Supremacy of the Kalamu'Llah
}

\author{
MOHD SHAHRIZAL NASIR
}

\begin{abstract}
Pusat Pengajian Bahasa Arab, Fakulti Bahasa dan Komunikasi, Universiti Sultan Zainal Abidin Kampus Gong Badak, 21300 Kuala Nerus, Terengganu.

mohdshahrizal@unisza.edu.my
\end{abstract}

Abstrak Elipsis atau al-hadhf merupakan satu uslub yang terdapat dalam bahasa Arab dan juga bahasa lain di dunia. Uslub berperanan menyerlahkan keindahan sesuatu bahasa kerana mempamerkan kepelbagaian gaya bahasa dalam menyampaikan makna ayat. Al-Quran yang diturunkan oleh Allah SWT kepada Rasulullah SAW dan umatnya menggunakan bahasa Arab standard. Oleh itu, kewujudan elipsis atau al-hadhf dalam al-Quran menunjukkan bahawa pemahaman terhadap ayat al-Quran memerlukan pengetahuan yang baik tentang tatabahasa Arab. Hal ini menjelaskan bahawa ayat al-Quran tidak boleh ditafsir oleh orang awam tanpa penguasaan ilmu tatabahasa Arab. Namun begitu, hal ini tidak membawa pengertian bahawa ayat-ayat al-Quran sukar untuk difahami. Makalah ini membincangkan kewujudan elipsis ( $a l$-hadhf) dalam bahasa Arab dan kewujudannya dalam al-Quran. Beberapa ayat al-Quran dianalisis bagi memahami elipsis (alhadhf) dan fungsinya dalam membawa makna ayat al-Quran secara jelas. Dapatan analisis menunjukkan bahawa pemahaman elipsis (al-hadhf) mempunyai kaitan yang rapat dengan kaedah tatabahasa Arab atau al-Nahw al- 'Arabiy. Justeru, penguasaan terhadap tatabahasa Arab merupakan satu keperluan dalam memahami ayat-ayat al-Quran.

Kata kunci: Elipsis, al-hadhf, uslub, tatabahasa Arab, retorik Arab.

Abstract Ellipsis or al-hadhf is one of the language styles which exists in Arabic and other languages in the world. This language style highlights the beauty of the language in displaying the diversity of language styles in conveying the meaning of sentences. The Holy Quran, which was revealed by the Almighty Allah to the Prophet (p.b.u.h.) and the Muslims, used the 
standard form of the Arabic language. Therefore, ellipsis or al-hadhf that exists in the verses of the Quran shows that understanding of the Quranic verses requires a good knowledge of the Arabic syntax. This explains that the Quranic verses cannot be interpreted by the public without the mastery of Arabic syntax. However, this does not imply that the Quranic verses are difficult to be understood. This paper discussed the existence of ellipsis (al-hadhf) in the Arabic language and its existence in the Quran. Some of the Quranic verses were analysed to understand the style of ellipsis (alhadhf) and its functions to bring forth a greater clarity of the meaning of the Quranic verses. The result of the analysis showed that the understanding of ellipsis (al-hadhf) has a close relation with the Arabic syntax rules or al-Nahw al-'Arabiy. Hence, the mastery of Arabic syntax is essential in understanding the verses of the Quran.

Keywords: Ellipsis, al-hadhf, language style, Arabic syntax, Arabic rhetoric.

\section{PENDAHULUAN}

Bahasa Arab merupakan bahasa yang dipilih untuk membawa wahyu daripada Allah SWT. Al-Quran merupakan wahyu terakhir yang diturunkan kepada Rasulullah SAW menggunakan bahasa Arab. Bahasa Arab mempunyai ciri-ciri tersendiri dalam pembentukan sesuatu ayat, iaitu merujuk kepada aspek tatabahasa, retorika dan semantik. Ciri istimewa yang terdapat dalam bahasa Arab ialah elipsis atau al-hadhf atau diterjemahkan dalam bahasa Melayu mudah sebagai elipsis atau pengguguran. Jika diteliti pada kitab-kitab bahasa, perbincangan tentang elipsis ( $a l$-hadhf) termasuk dalam bidang retorik Arab atau disebut al-Balaghah al-'Arabiyyah.

Elipsis (al-hadhf) merupakan satu uslub atau gaya bahasa yang melibatkan lafaz dan makna dalam sesuatu ayat. Perkataan al-hadhf secara etimologi berasal daripada kata ( - - (ح) yang dapat diertikan sebagai penghapusan atau pengguguran. Secara terminologi, perkataan alhadhf dalam ilmu tatabahasa Arab bermakna pengguguran sesuatu aspek tatabahasa Arab. Dari sudut ilmu Balaghah, al-hadhf membawa maksud menjatuhkan atau menggugurkan sesuatu struktur bahasa sama ada banyak 
ataupun sedikit. Kewujudan al-hadhf merujuk kepada pengguguran huruf atau lafaz atau ayat yang tidak akan merosakkan makna sesuatu ayat secara keseluruhannya dengan alasan-alasan tertentu. Al-hadhf adalah salah satu daripada sejumlah besar kaedah dalam sistem tatabahasa Arab.

Namun, jika elipsis (al-hadhf) dikaitkan dengan al-Quran, perlu difahami bahawa pemahaman tentang al-hadhf tidak sekali-kali memberi petunjuk bahawa al-Quran itu tidak sempurna kerana berlaku pengguguran pada perkataan-perkataan tertentu. Pemahaman salah seperti ini perlu diperbetulkan dan tidak boleh dikompromi kerana Allah SWT secara jelas telah menyatakan bahawa al-Quran adalah Kalamu'Llah yang sempurna serta tiada sebarang keraguan di dalamnya. Al-hadhf yang melibatkan ayat al-Quran adalah berdasarkan pandangan para ilmuan tafsir tatkala mentafsirkan sesuatu ayat dengan mengikut hukum tatabasa Arab yang disepakati. Sebagai contoh, sekiranya dalam sesuatu ayat al-Quran terdapat mubtada' (subjek), maka sudah pasti wujud khabar (predikat). Namun, ketiadaan salah satu daripada dua elemen ini dalam sesuatu ayat menunjukkan wujudnya gaya bahasa yang disebut sebagai al-hadhf. Selain itu, perlu difahami bahawa pengguguran sesuatu perkataan pada ayat alQuran sepertimana yang dinyatakan oleh para ilmuwan tafsir, tidak sekalikali mengaburkan ayat tersebut, malah membawa makna tersendiri yang lebih jelas bersesuaian dengan konteks ayat.

Makalah ini akan menghuraikan al-hadhf dalam al-Quran dan hubungannya dengan makna yang terdapat di sebalik uslub atau gaya bahasa ini. Skop analisis tertumpu kepada al-hadhf yang melibatkan kalimah atau perkataan pada ayat al-Quran. Perkataan yang terlibat dengan al-hadhf dilihat berdasarkan kedudukan fleksinya dalam ayat.

\section{TAKRIFAN ELIPSIS (AL-HADHF)}

Secara umum, al-hadhf ialah pengguguran satu bahagian dalam ayat sama ada huruf, perkataan, tarkib dan ayat dengan syarat terdapat dilalah (petunjuk) yang menunjukkan terdapat elemen yang digugurkan dalam pertuturan atau penulisan (al-Samirra'iy, 1998). Hal ini berlaku dengan 
tujuan tertentu. Tujuan yang dikaitkan dengan al-hadhf ini mempunyai perkaitan rapat dengan ilmu retorik Arab. Antara tujuan penggunaan alhadhf adalah untuk menunjukkan perkara yang positif seperti meringkaskan, memberi peringatan, meringankan, memuliakan serta memberi maksud umum dalam pertuturan atau penulisan. Namun begitu, terdapat juga penggunaan al-hadhf yang membawa maksud lain, iaitu untuk tujuan sindiran atau penghinaan (Abu Shadiy, 1992).

Terdapat beberapa pendapat yang bersetuju dengan kewujudan al-hadhf pada ayat khususnya ayat-ayat al-Quran. Pada era mutakhir ini, antara individu yang menghasilkan buku tentang al-hadhfialah Abu Shadiy (1992), al-Samirra'iy (1998) dan Fayyud (1998). Namun begitu, terdapat juga sarjana lain yang menolak kewujudan al-hadhf khususnya dalam alQuran. Antara sarjana tersebut ialah Fadl Hasan 'Abbas yang menjelaskan pendiriannya terhadap al-hadhf di dalam bukunya, Lata 'if al-Mannan wa Rawa 'i al-Bayan fi Nafy al-Ziyadah wa al-Hadhf fi al-Qur'an (2010). Menurut Fadl Hasan 'Abbas, al-Quran merupakan wahyu Allah SWT yang diturunkan dalam keadaan sempurna dan tidak terdapat sebarang pengguguran di dalam al-Quran sama ada satu huruf, perkataan, tarkib mahupun ayat.

Menurut Tammam Hassan (1994) pula, apabila membicarakan uslub al-hadhf, ia tidak boleh difahami bahawa al-hadhf hanya berlaku apabila salah satu unsur dalam ayat digugurkan, tetapi sebenarnya al-hadhf merupakan satu uslub bahasa yang membezakan antara sistem atau kaedah bahasa dengan keperluan sesuatu ayat yang perlu bersesuaian dengan konteks tertentu. Oleh itu, ada kalanya sesuatu unsur bahasa itu dinyatakan dalam ayat dan ada kalanya digugurkan daripada ayat.

Makalah ini memfokus pada kewujudan al-hadhf dalam al-Quran dan perkaitannya dengan kaedah tatabahasa Arab. Huraian berkaitan uslub atau gaya bahasa ini adalah sepertimana yang telah disepakati oleh para mufassir dan sarjana yang bersetuju dengan kewujudan al-hadhf di dalam al-Quran. Makalah ini turut menghuraikan empat kategori utama al-hadhf di dalam al-Quran. Kategori tersebut adalah seperti berikut: 
1) Hadhf al-huruf(Elipsis huruf)

2) Hadhf al-kalimah (Elipsis perkataan)

3) Hadhf al-jumlah (Elipsis ayat)

4) Hadhf al-tarkib (Elipsis rangkaian ayat)

\section{Hadhf al-huruf (Elipsis huruf)}

Kategori pertama melibatkan hadhf al-huruf (elipsis huruf). Perkara ini dapat difahami menerusi firman Allah SWT dalam Surah al-Nisa', ayat 176:



Terjemahan: Mereka (orang Islam umatmu) meminta fatwa kepadamu (wahai Muhammad, mengenai masalah Kalalah). Katakanlah: "Allah memberifatwa kepada kamu dalam perkara Kalalah itu, iaitujika seseorang mati yang tidak mempunyai anak dan ia mempunyai seorang saudara perempuan, maka bagi saudara perempuan itu seperdua daripada harta yang ditinggalkan oleh si mati; dan ia pula (saudara lelaki itu) mewarisi (semua harta) saudara perempuannya, jika saudara perempuannya tidak mempunyai anak. Kalau pula saudara perempuannya itu dua orang, maka keduanya mendapat dua pertiga daripada harta yang ditinggalkan oleh si mati. Dan sekiranya mereka (saudara-saudaranya itu) ramai, lelaki dan perempuan, maka bahagian seorang lelaki menyamai bahagian dua orang perempuan". Allah menerangkan (hukum ini) kepada kamu supaya kamu tidak sesat. Dan (ingatlah) Allah Maha Mengetahui akan tiap-tiap sesuatu.

Tafsiran makna ayat 176 daripada Surah al-Nisa' dapat difahami sepertimana berikut:

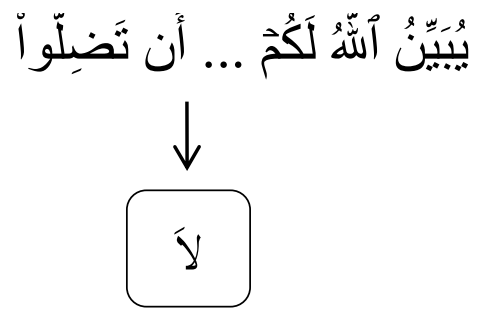


Pada ayat ini terdapat hadhf al-huruf sepertimana yang dijelaskan oleh para mufassir (Abu Shadiy, 1992). Ayat ini menyentuh soal pembahagian harta pusaka melibatkan saudara perempuan (Ibn Kathir, 2004: 41/815). Jika dilihat secara zahir ayat, huruf yang gugur pada ayat ini ialah huruf [У] yang membawa maksud penafian. Penjelasan mengenai pembahagian harta pusaka yang melibatkan saudara perempuan dijelaskan pada ayat ini supaya manusia tidak sesat, dan bukan bermaksud sebaliknya, meskipun secara zahir ayat tidak terdapat [ [ $]$ ] yang membawa maksud penafian, iaitu "tidak sesat" pada ayat ini.

\section{Hadhf al-kalimah (Elipsis perkataan)}

Kategori kedua pula melibatkan hadhf al-kalimah (elipsis perkataan). Perkara ini dapat difahami menerusi firman Allah SWT dalam Surah alKahf, ayat 79 :



Terjemahan: Adapun perahu itu adalah ia dipunyai oleh orang miskin yang bekerja di laut; oleh itu, aku bocorkan dengan tujuan hendak mencacatkannya, kerana di belakang mereka nanti ada seorang raja yang merampas tiap-tiap sebuah perahu yang tidak cacat.

Tafsiran makna ayat 79 daripada Surah al-Kahf dapat difahami sepertimana berikut:

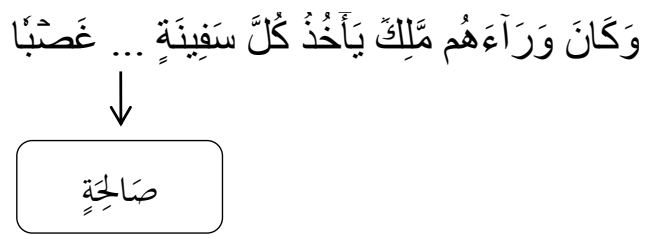

Pada ayat 79 daripada Surah al-Kahf ini terdapat hadhf al-kalimah (Abu Shadiy, 1992). Ayat ini berkaitan kisah Khidir a.s. dan Nabi Musa a.s. tatkala Khidir membocorkan perahu milik golongan yang miskin (Ibn Kathir, 2004: 3/1736). Tindakan Khidir a.s. adalah mengelak berlaku kezaliman oleh raja ke atas golongan miskin melalui tindakannya merampas setiap perahu 
yang berada dalam keadaan baik. Namun, pada zahir ayat, tidak terdapat perkataan yang menjelaskan perihal keadaan perahu yang menjadi idaman raja yang zalim tersebut. Perkataan yang dimaksudkan ialah [صالحة] yang membawa maksud selamat atau tidak rosak.

\section{Hadhf al-jumlah (Elipsis ayat)}

Kategori seterusnya ialah hadhf al-jumlah (elipsis ayat). Kategori ini dapat difahami menerusi firman Allah SWT dalam Surah al-Nahl, ayat 30:



Terjemahan: Dan ditanya kepada orang yang bertakwa: "Apakah yang telah diturunkan oleh Tuhan kamu?" Mereka menjawab: "Kebaikan”. Orang yang berbuat kebaikan di dunia ini beroleh balasan yang baik, dan sesungguhnya balasan negeri akhirat itu lebih baik lagi; dan memanglah negeri akhirat ialah sebaik-baik negeri bagi orang yang bertakwa.

Tafsiran makna ayat 30 daripada Surah al-Nahl dapat difahami sepertimana berikut:

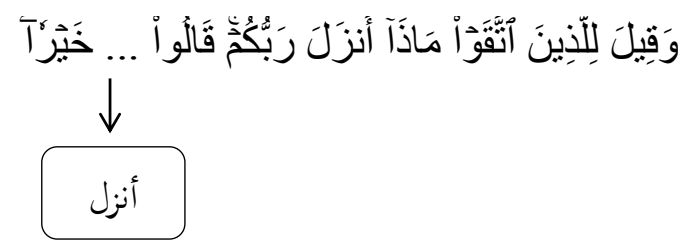

Ayat ini merakamkan keadaan orang yang bertakwa tatkala ditanya oleh Allah SWT tentang apakah yang diturunkan atau dianugerahkan oleh Allah SWT kepada mereka. Maka, golongan hamba Allah SWT yang bertakwa ini menjawab bahawa sesungguhnya Allah SWT telah menganugerahkan kepada mereka kebaikan yang berupa rahmat dan berkat (Ibn Kathir, 2004: 2/1570-1571). Namun, pada ayat 30 Surah al-Nahl ini, berdasarkan zahir ayat, golongan yang bertakwa hanya menyebut kebaikan atau ['خير'] sahaja. Jika ditafsirkan secara keseluruhan, berlaku hadhf al-jumlah pada ayat atau jumlah yang melibatkan al-jumlah al-fi 'liyah [ [أنزد yang terdiri 
daripada $f$ ' $l$ dan $f a$ 'il, iaitu Allah SWT. Menurut Abu Shadiy (1992), berlaku hadhf al-jumlah pada ayat ini adalah untuk tujuan ringkasan atau ikhtisar.

\section{Hadhf al-tarkib (Elipsis rangkaian ayat)}

Bagi kategori keempat pula, ia melibatkan hadhf al-tarkib (elipsis rangkaian ayat). Kategori ini dapat difahami menerusi firman Allah SWT dalam Surah al-Ahzab, ayat 37:

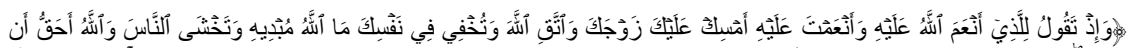

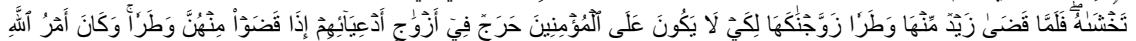

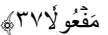

Terjemahan: Dan (ingatlah wahai Muhammad) ketika kamu berkata kepada orang yang telah dikurniakan oleh Allah (dengan nikmat Islam) dan yang kamu juga telah berbuat baik kepadanya: "Jangan ceraikan isterimu itu dan bertakwalah kepada Allah", sambil kamu menyembunyikan dalam hatimu perkara yang Allah akan menyatakannya; dan kamu pula takut kepada (cacian) manusia padahal Allah jualah yang berhak kamu takuti (melanggar perintah-Nya). Kemudian setelah Zaid selesai habis kemahuannya terhadap isterinya dengan menceraikannya, Kami kahwinkan kamu dengannya supaya tidak ada keberatan atas orang mukmin untuk berkahwin dengan isteri-isteri anak angkat mereka, apabila mereka telah habis kemahuan terhadap isterinya dengan bercerai. Dan sememangnya perkara yang dikehendaki Allah itu tetap berlaku.

Tafsiran makna ayat 37 daripada Surah al-Ahzab dapat difahami sepertimana berikut:



Berlaku hadhf al-tarkib pada ayat 37 daripada Surah al-Ahzab. Menurut Abu Shadiy (1992), hadhf al-tarkib melibatkan pengguguran lebih daripada satu ayat. Ayat yang dibincangkan ini berkenaan peristiwa 
Rasulullah SAW diperintahkan Allah SWT untuk menikahi bekas isteri kepada anak angkatnya, iaitu Zayd b. Harithah (Ibn Kathir, 2004: 3/22552256). Dari sudut makna ayat, berlaku hadhf al-tarkib pada ayat ini yang maknanya difahami berdasarkan ketiadaan tarkib yang menjelaskan makna keseluruhan ayat. Makna ini difahami berdasarkan ketetapan hukum perkahwinan yang sudah sedia dimaklumi, iaitu seseorang wanita yang telah diceraikan oleh suaminya dibenarkan berkahwin dengan lelaki lain setelah tamat tempoh 'iddah.

Penjelasan terperinci inilah yang tidak dinyatakan secara zahir melalui lafaz-lafaz ayat pada ayat 37 Surah al-Ahzab ini. Namun, ia tetap dapat difahami secara jelas. Selain itu, dapat difahami bahawa ayat ini memberi fokus kepada isu keharusan menikahi bekas isteri kepada anak angkat, maka penjelasan mengenai hukum menikahi janda secara umum selepas melalui tempoh 'iddah bukan menjadi fokus utama kerana ia telah sedia dimaklumi. Oleh itu, hadhf al-tarkib pada ayat ini tidak sekali-kali mencacatkan makna ayat keseluruhannya.

\section{PERKAITAN ANTARA USLUB $A L-H A D H F$ DENGAN MAKNA AYAT}

Para sarjana telah membahagikan al-hadhf kepada beberapa jenis. Pada bahagian ini, beberapa analisis dibuat melibatkan ayat-ayat al-Quran dan hanya tertumpu kepada al-hadhf yang melibatkan perkataan atau al-kalimah . Menurut al-Mut'aniy (1992), al-hadhf yang melibatkan perkataan boleh dibahagikan kepada beberapa bentuk, ialah:

1) Hadhfal-fi'l (Elipsis kata kerja)

2) Hadhf al-fa 'il (Elipsis kata nama pelaku)

3) Hadhf al-maf'ul bih (Elipsis kata nama sasaran kata kerja)

4) Hadhf al-mubtada'(Elipsis subjek)

5) Hadhf al-khabar (Elipsis predikat)

6) Hadhf al-mawsuf (Elipsis kata nama yang dikaitkan dengan kata sifat)

7) Hadhf al-sifah (Elipsis kata sifat atau adjektif) 
8) Hadhf al-mudaf (Elipsis kata majmuk)

9) Hadhf al-mudafilayh (Elipsis kata majmuk)

Kesemua bentuk al-hadhf ini membawa pengertian bahawa alhadhf yang melibatkan perkataan berkait rapat dengan kedudukan sesuatu perkataan yang membawa makna tertentu dan dikenali sebagai i $r a b$ atau fleksi. Kamarul Shukri (2005) menukilkan pendapat para sarjana tentang makna fleksi dari sudut bahasa dan istilah dalam bukunya bertajuk Tatabahasa Arab dan Pembinaan Hukum daripada al-Quran. Dari segi bahasa, $i$ 'rab atau fleksi bermaksud menerangkan dan menjelaskan sesuatu perkara (Ibn Manzur, 1994).

Dari segi istilah pula, fleksi didefinisikan sebagai perubahan pada akhir perkataan yang berlaku secara lafzi dan zahir atau secara taqdiri, hasil daripada wujudnya 'amil yang tertentu (Ibn Hisham, 2000). Menurut Kamarul Shukri (2005), para sarjana bersepakat tentang kepentingan fleksi dalam memperjelas dan menerangkan makna-makna yang terdapat pada sesuatu perkataan dalam ayat. Makna yang dibawa oleh sesuatu perkataan amat bergantung kepada kedudukan fleksi perkataan tersebut dalam ayat.

Daripada penjelasan makna fleksi, dapat difahami bahawa setiap perkataan yang terlibat dengan al-hadhf akan mengubah makna ayat secara keseluruhan. Hal ini disebabkan setiap perkataan yang diletakkan bagi menyempurnakan satu binaan ayat mempunyai fungsi tersendiri dalam menyampaikan maksud ayat tersebut. Oleh itu, ketiadaan perkataan tertentu pada ayat akan melibatkan perubahan makna ayat tersebut secara keseluruhan.

Pada keadaan tertentu, al-hadhf mungkin masih mengekalkan makna utama ayat tersebut. Namun, ia tetap membawa fungsi tertentu yang melibatkan aspek makna dalaman ayat. Hal inilah yang akan dilihat berdasarkan analisis yang dibuat terhadap beberapa ayat al-Quran yang terlibat dengan al-hadhf.

Beberapa ayat al-Quran yang mempunyai kaitan dengan al-hadhf akan dianalisis berdasarkan keadaan perkataan yang mempunyai kedudukan fleksi tertentu dalam ayat al-Quran. Perbincangan akan dibuat mengikut 
bentuk-bentuk al-hadhf sepertimana yang dinyatakan oleh al-Mut'aniy (1992). Bagi setiap bentuk, satu contoh akan diberikan berserta huraian yang memberi fokus kepada uslub al-hadhf yang terdapat dalam ayat al-Quran.

\section{1) Hadhf al-fi'l (Elipsis kata kerja)}

Firman Allah SWT di dalam al-Quran, daripada Surah al-Shams ayat 13:

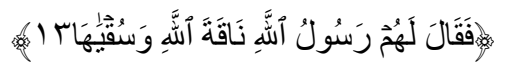

Terjemahan: Maka berkatalah Rasul Allah (Nabi Salih) kepada mereka: "(Janganlah kamu ganggu) unta betina daripada Allah itu dan (janganlah kamu menyekatnya daripada mendapat) air minumannya (supaya kamu tidak ditimpa azab)!’”.

Ayat 13 Surah al-Shams ini merakamkan kisah Nabi Salih a.s. yang memberi peringatan tegas atau amaran kepada kaumnya agar tidak memberi mudarat kepada unta betina iaitu naqah daripada Allah SWT (Al-Sabuniy, 1979: 3/548). Menurut tafsiran Ibn Kathir, terdapat $f$ ' $l$ atau kata kerja yang gugur atau disebut mahdhuf dalam ayat ini (2004: 4/3047). Kata kerja yang dimaksudkan ialah [احذرو'], iaitu fi'l al-amr atau kata kerja arahan. Kata kerja yang digugurkan ini terletak sebelum perkataan naqah.

Perlu dijelaskan bahawa apabila disebut sesuatu perkataan itu "gugur" ia bukan membawa maksud ayat tersebut cacat atau tidak sempurna. Sebaliknya, pengguguran atau al-hadhf ini merujuk kepada pemahaman makna ayat tersebut mengikut kaedah tatabahasa secara asas. Ketiadaan $f$ ' $l$ atau kata kerja pada ayat ini memberi petunjuk berlaku uslub al-hadhf yang membawa makna tertentu.

Al-Mut'aniy (1992) menyatakan bahawa dari sudut retorika Arab, di antara rahsia berlakunya al-hadhf pada ayat ini ialah untuk tujuan amaran keras atau disebut [تحذير]. Sekali lagi dijelaskan bahawa meskipun perkataan [احذرو'] tiada dalam ayat, ia tidak sesekali membawa pengertian bahawa ayat al-Quran ini tidak sempurna, sebaliknya ketiadaan perkataan tersebut semakin menjelaskan makna ayat yang membawa unsur amaran keras daripada Nabi Salih a.s. kepada kaumnya. 


\section{2) Hadhf al-fa'il (Elipsis kata nama pelaku)}

Firman Allah SWT di dalam al-Quran, daripada Surah Sad, ayat 32:

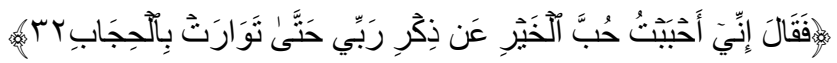

Terjemahan: (Kerana lekanya dengan pertunjukan itu) maka nabi Sulayman berkata: "Sesungguhnya aku telah mengutamakan kesukaanku kepada (kuda pembawa) kebaikan lebih daripada mengingati (ibadatku kepada) Tuhanku, sehingga (matahari) melindungi dirinya dengan tirai malam.

Terdapat banyak pendapat tentang pentafsiran ayat 32 daripada Surah Sad. Namun dalam pentafsiran ayat, banyak pendapat menyatakan bahawa berlaku al-hadhf pada fa' $i l$ atau pelaku bagi al-fi'l al-madiy (kata kerja lepas), iaitu tawarat (al-Mut'aniy, 1992). Dalam hukum tatabahasa Arab, setiap $f^{\prime} l$ atau kata kerja mesti disertakan bersamanya pihak yang melakukan kata kerja tersebut. Pendapat yang kuat menyatakan pihak yang terlibat bagi kata kerja tawarat pada ayat ini ialah matahari atau disebut alshams (Al-Sabuniy, 1979: 3/57). Matahari merupakan antara bintang yang besar sifatnya. Justeru, pengguguran perkataan al-shams yang bertindak sebagai fa il dalam ayat ini membawa tujuan mengukuhkan kemunculan matahari dengan sifatnya yang diketahui umum kemudian terlindung dengan halangan tertentu.

Pendapat yang merujuk bahawa fa 'il yang digugurkan daripada ayat 32 daripada Surah Sad ini ialah matahari semakin jelas apabila kata kerja tawarat yang terdapat pada ayat tersebut dalam bentuk feminin. Hal ini memandangkan matahari atau al-shams termasuk dalam kategori feminin. Menurut al-Mut'aniy (1992), berlaku al-hadhf pada fa 'il dalam ayat ini sejajar dengan kedudukan makna fa il yang sedia dimaklumi oleh umum. Keadaan ini bertepatan dengan kaedah yang menyatakan bahawa pengguguran sesuatu yang diketahui adalah diharuskan (hadhf ma yu 'lam ja'iz).

\section{3) Hadhf al-maf'ul bih (Elipsis kata nama sasaran kata kerja)}

Firman Allah SWT di dalam al-Quran, daripada Surah Yunus, ayat 25:

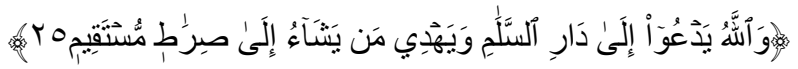


Terjemahan: (Itulah dia kesudahan kehidupan dunia), dan sebaliknya Allah menyeru manusia ke tempat kediaman yang selamat sentosa, dan Dia sentiasa memberi petunjuk hidayah-Nya kepada sesiapa yang dikehendakiNya (menurut undang-undang peraturan-Nya) ke jalan yang betul lurus (yang selamat itu).

Jika diperhatikan pada ayat 25 Surah Yunus ini, terdapat $f i$ ' atau kata kerja, iaitu yad' $u$. Kata kerja ini merujuk pada Allah SWT yang menyeru pihak tertentu untuk berusaha menuju ke syurga-Nya. Tetapi tidak kelihatan maf'ul bih pada ayat tersebut. Menurut pandangan sarjana, pada ayat ini telah berlaku al-hadhf melibatkan maf'ul bih yang merujuk kepada sesiapa sahaja yang berhak menerima ganjaran syurga.

Justeru, dapat difahami bahawa lafaz maf'ul bih (kata nama sasaran kata kerja) yang digugurkan pada ayat ini membawa tujuan mengumumkan makna lafaz yang merujuk kepada maf'ul bih. Sesiapa sahaja yang memperoleh rahmat daripada Allah SWT, termasuk dalam makna perkataan maf'ul bih selepas perkataan yad'u. Perkara yang dimaksudkan dengan maf'ul bih dalam uslub al-hadhf pada ayat 25 daripada Surah Yunus ini ialah kull ahad (Al-Mut'aniy, 1992). Hal ini menunjukkan bahawa maf'ul bih pada ayat ini dibuat secara umum, iaitu sesiapa sahaja yang menepati ciri-ciri yang ditetapkan oleh Allah SWT untuk menjadi penghuni syurga. Peluang menjadi penghuni syurga tidak dikhususkan pada golongan tertentu sahaja. Ia terbuka untuk setiap Muslim sama ada orang Arab atau bukan Arab, orang kaya atau miskin, berpangkat atau tidak berpangkat, kesemuanya dipelawa oleh Allah SWT untuk menjadi penghuni syurga-Nya.

Namun, al-Sabuniy menyatakan bahawa meskipun maf'ul bih yang tidak dinyatakan pada ayat ini adalah bersifat umum, tetapi pada ayat seterusnya, iaitu ayat 26 Surah Yunus dinyatakan bahawa terdapat ciri-ciri khusus bagi individu yang layak mendapat jemputan Allah SWT untuk menghuni syurga-Nya, iaitu mereka yang beriman dan beramal soleh (alSabuniy, 1979: 1/568). 


\section{4) Hadhf al-mubtada' (Elipsis subjek)}

Terdapat banyak tempat dalam al-Quran yang melibatkan al-hadhf bagi mubtada' (subjek) dan khabar (prediket) dalam ayat (al-Mut'aniy, 1992). Antaranya ialah pada ayat 9 daripada Surah al-Muzammil sebagaimana firman Allah SWT di dalam al-Quran:

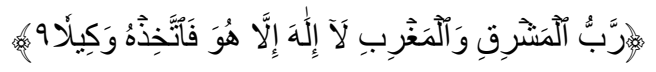

Terjemahan: Dialah Tuhan yang menguasai Timur dan Barat; tiada Tuhan melainkan Dia; makajadikanlah Dia Penjaga yang menyempurnakan urusanmu.

Pada ayat ini, telah berlaku hadhf mubtada', iaitu kata ganti nama [ه] yang terletak pada awal ayat dari sudut maknanya, sedangkan ayat ini dimulakan dengan khabar, iaitu [ربّ]. Menurut al-Mut'aniy (1992), alhadhf yang melibatkan mubtada' ini berlaku kerana kata ganti nama [هو] yang merupakan mubtada' tersebut merujuk kepada makna "Allah" atau Rabb. Al-Sabuniy menjelaskan secara terperinci bahawa ayat ini merujuk kepada Allah SWT (Al-Sabuniy, 1979: 3/455).

Jika diteliti pada ayat 8 daripada Surah al-Muzammil, secara jelas perkataan [ربّك] merujuk kepada Allah SWT, maka ia dikaitkan secara langsung dengan ayat berikutnya, iaitu ayat 9 yang dibincangkan. Antara rahsia berlakunya uslub al-hadhf ini disebabkan pengulangan sesuatu yang telah dimaklumkan pada ayat sebelumnya adalah sesuatu yang tidak perlu (Al-Mut'aniy, 1992: 2/36). Pengguguran mubtada' pada ayat ini tidak menjejaskan makna ayat kerana ia telah sedia dinyatakan dan dimaklumi daripada ayat-ayat sebelumnya.

\section{5) Hadhf al-khabar (Elipsis predikat)}

Sebagaimana berlakunya al-hadhf bagi mubtada' (subjek), terdapat juga al-hadhf pada perkataan yang terletak pada kedudukan khabar (predikat) dalam ayat. Khabar hanya akan wujud dalam sesuatu ayat sekiranya terdapat mubtada'. Hal ini bermakna, mubtada' dan khabar adalah dua elemen penting yang memerlukan antara satu sama lain. Menurut al-Rajihiy (1988) di dalam bukunya al-Tatbiq al-Nahw, wujudnya khabar (predikat) dalam 
sesuatu ayat adalah disebabkan kewujudan mubtada' (subjek) sehingga mubtada' dikenali sebagai 'amil (penyebab) kepada wujudnya khabar.

Pada ayat 50 daripada Surah al-Shu'ara' berikutnya, terdapat al-hadhf yang melibatkan khabar. Firman Allah SWT di dalam al-Quran:

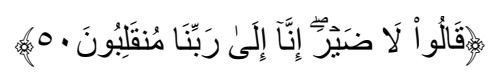

Terjemahan: Mereka menjawab: "(Ugutanmu itu) tidaklah menjadi hal! Sesungguhnya kami (tidak gentar), kerana kepada Tuhan kamilah kembalinya kami.

Ayat ini merupakan firman Allah SWT yang berkaitan dengan katakata ahli sihir tatkala mereka diancam dengan hukuman oleh Fir'aun (Ibn Kathir, 2004:3/2053). Khabar yang dimaksudkan ialah perkataan [علين], iaitu pada kedudukan selepas perkataan [لا ضير] (Al-Sabuniy, 1979: 2/363; alMut'aniy, 1992). Khabar ini termasuk dalam khabar jenis shibh al-jumlah, iaitu yang merujuk kepada al-jar [على] dan al-majrur ["نمير "ضالن].

Antara rahsia uslub al-hadhf pada ayat ini adalah bertujuan meringkaskan ayat atau disebut sebagai [الإيجاز]. Walau bagaimanapun, makna ayat tetap sempurna, tambahan pula ia melibatkan ungkapan yang diungkapkan oleh ahli sihir yang menafikan kekhuatiran mereka terhadap sebarang ugutan berbentuk hukuman daripada Firaun ke atas mereka. Hal ini demikian kerana para ahli sihir beriman dengan Allah SWT serta meyakini kekuasaan-Nya selepas menyaksikan mukjizat Nabi Musa a.s.

\section{6) Hadhf al-mawsuf (Elipsis kata nama yang dikaitkan dengan kata sifat)}

Al-Hadhf juga berlaku pada ayat al-Quran yang melibatkan sifah (kata sifat atau adjektif) dan mawsuf (kata nama yang dikaitkan dengan kata sifat). Namun, hadhf al-mawsuf dilihat lebih banyak daripada al-hadhf yang melibatkan sifah (al-Mut'aniy, 1992). Mawsuf lebih kuat kedudukannya dalam ayat berbanding dengan sifah. Sekiranya terdapat sifah dalam sesuatu ayat, pastinya ia merujuk kepada sesuatu yang disifatkan atau disebut mawsuf. Dengan kata lain, sifah akan sentiasa disandarkan kepada mawsuf 
tertentu. Sifah tidak akan wujud pada sesuatu ayat tanpa wujudnya mawsuf.

Contoh hadhf yang melibatkan perkataan pada kedudukan mawsuf sepertimana pada ayat 52 Surah Sad. Firman Allah SWT di dalam al-Quran:

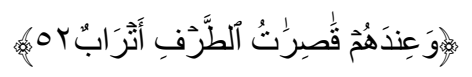

Terjemahan: Dan di sisi mereka pula para bidadari yang pandangannya tertumpu (kepada mereka semata-mata), lagi yang sebaya umurnya.

Pada ayat ini terdapat dua sifah (kata sifat atau adjektif), iaitu [قاصر ات الطرف] yang merujuk kepada pandangan mata yang tertumpu, dan juga [أتراب yang merujuk kepada umur yang sebaya (Al-Sabuniy, 1979: 3/60). Kedua-dua sifah ini disandarkan kepada ciri-ciri para bidadari syurga atau disebut sebagai [حور] (Ibn Kathir, 2004: 4/2432; al-Sabuniy, 1979:3/60).

Pada ayat al-Quran ini, berlaku al-hadhf pada perkataan [حور] yang merujuk kepada para bidadari syurga. Namun begitu, ciri-ciri bidadari tersebut dijelaskan pada ayat 52 daripada Surah Sad. Secara jelas dapat dilihat bahawa berlaku al-hadhf pada mawsuf, sedangkan sifah dinyatakan. Antara rahsia berlakunya al-hadhf pada mawsuf ialah keutamaan menyerlahkan sifah berbanding mawsuf (al-Mut'aniy, 1992). Allah SWT memerihalkan keistimewaan dan keindahan para bidadari dengan menyerlahkan sifatnya yang menarik, sesuai sebagai ganjaran istimewa bagi hamba-Nya yang beriman.

Pengguguran lafaz perkataan mawsuf (kata nama yang dikaitkan dengan kata sifat) tidak mencacatkan makna dan tujuan pemerihalan para bidadari yang terdapat di dalam syurga. Menurut Ibn 'Abbas, Mujahid, Sa'id bin Jubayr dan Muhammad bin Ka'b, ayat ini dan beberapa ayat lagi sebelumnya memerihalkan tentang kenikmatan syurga yang disediakan untuk para hamba Allah SWT yang bertakwa selepas mereka dibangkitkan dari kubur serta terselamat daripada neraka (Ibn Kathir, 2004: 4/2432). 


\section{7) Hadhf al-sifah (Elipsis kata sifat atau adjektif)}

Firman Allah SWT di dalam al-Quran, daripada Surah al-Kahf, ayat 79:

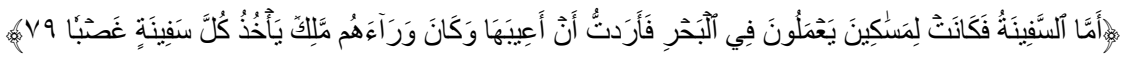

Terjemahan: Adapun perahu itu adalah ia dipunyai oleh orang miskin yang bekerja di laut; oleh itu, aku bocorkan dengan tujuan hendak mencacatkannya, kerana di belakang mereka nanti ada seorang raja yang merampas tiap-tiap sebuah perahu yang tidak cacat.

Bagi al-hadhf yang melibatkan sifah (kata sifat atau adjektif), ia boleh dilihat pada ayat 79 daripada Surah al-Kahf. Ayat ini merupakan penjelasan Khidir a.s. kepada Nabi Musa a.s. atas tindakannya membocorkan perahu milik golongan yang miskin dan lemah (Ibn Kathir, 2004: 3/1736; al-Sabuniy, 1979: 2/192). Pada akhir ayat ini dinyatakan sebab mengapa tindakan tersebut berlaku, iaitu untuk mengelak daripada kezaliman raja yang akan merampas setiap perahu yang berada dalam keadaan baik.

Pada ayat ini juga dinyatakan mawsuf, iaitu perahu atau disebut [سفينة], namun tidak dinyatakan sifah atau ciri perahu yang dikehendaki oleh raja tersebut. Para mufassir telah menjelaskan bahawa raja yang zalim hanya merampas perahu yang tidak rosak. Sifah yang tidak dinyatakan secara zahir pada ayat ini merujuk kepada perkataan [صالحة] yang membawa maksud tidak rosak (al-Sabuniy, 1979: 2/192). Ibn Kathir di dalam kitab tafsirnya menyatakan bahawa menurut bacaan Ubay bin Ka ${ }^{\circ} \mathrm{b}$, bahagian akhir ayat ini dibaca dengan [كل سفينة صالحة] (Ibn Kathir, 2004: 3/1736).

Antara rahsia berlakunya hadhf sifah pada ayat ini ialah untuk memberi gambaran ketamakan dan kerakusan raja yang zalim sehingga seolah-olah setiap perahu yang ditemuinya akan dirampas dengan kejam, tanpa mengira sama ada sesuatu perahu itu rosak mahupun sebaliknya (al-Mut'aniy, 1992). Berdasarkan pendapat ini, difahami bahawa gaya bahasa atau uslub al-hadhf ini mempunyai fungsi besar dalam pemahaman makna ayat. Pengguguran perkataan pada sesuatu ayat tidak sekali-kali mencacatkan makna ayat, malah menambah kejelasan makna ayat tersebut. 


\section{8) Hadhf al-mudaf (Elipsis kata majmuk)}

Al-Hadhf yang melibatkan perkataan juga berlaku pada perkataan yang kedudukan fleksinya mudaf [مضاف]. Dalam bahasa Arab, mudaf adalah salah satu komponen dalam penggabungan dua perkataan yang membawa makna tertentu. Penggabungan ini disebut sebagai idafah [إضافة]. Satu lagi komponen idafah dikenali sebagai mudaf ilayh [مضاف إليه]. Contoh perkataan yang termasuk dalam kategori idafah ialah perkataan Surah alFatihah [سورة الفاتحة] merupakan mudaf, manakala [سورة] Perkataan [الفاتحة] merupakan mudafilayh.

Pada bahagian ini, fokus akan diberikan kepada ayat 82 daripada Surah Yusuf. Firman Allah SWT di dalam al-Quran:

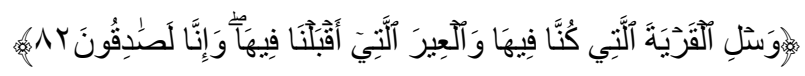

Terjemahan: "Dan bertanyalah kepada penduduk negeri (Mesir) tempat kami tinggal (berdagang) dan kepada orang kafilah yang kami balik bersamanya. Sesungguhnya kami adalah orang yang benar".

Pada ayat ini berlaku hadhf mudaf, iaitu komponen pertama bagi idafah. Ayat ini merupakan ayat yang merujuk kepada saudara Nabi Yusuf a.s. bagi meyakinkan bapanya bahawa mereka dalam kalangan orang yang bercakap benar (Ibn Kathir, 2004: 2/1464). Hal ini berkaitan pertuduhan mencuri cupak raja yang dikenakan kepada saudara mereka, Bunyamin. Para saudara Nabi Yusuf a.s. menyarankan kepada bapa mereka, iaitu Nabi Ya'qub a.s. agar menanyakan sendiri kepada penduduk Mesir tentang hal ini sekiranya masih ragu dengan kesahihannya.

Pada ayat ini, mudaf telah digugurkan, iaitu perkataan [أهل], manakala mudaf ilayh dikekalkan, iaitu perkataan [القرية]. Maka, perkataan idafah yang terdapat pada ayat ini ialah [أهل القرية] atau secara spesifik merujuk kepada [أهل مصر (Al-Sabuniy, 1979: 2/63). Persoalan yang timbul, bagaimana mungkin diajukan pertanyaan kepada sesebuah kampung atau tempat. Sebenarnya, pertanyaan diajukan kepada penduduk yang menghuni tempat tersebut. Hal ini menunjukkan telah berlaku al-hadhf pada perkataan yang kedudukan fleksinya mudaf pada ayat ini. 
Antara rahsia berlakunya al-hadhf pada ayat ini ialah untuk menunjukkan keadaan "terlampau" atau disebut مبالغة] dalam menyatakan kebenaran bagi pihak saudara-saudara Nabi Yusuf a.s. Oleh itu, pertanyaan wajar diajukan buat seluruh manusia yang menghuni kampung atau tempat tersebut. Dalam ilmu retorik Arab, keadaan ini juga termasuk dalam bab majaz al-mursal [مجاز المرسل] yang perkaitannya termasuk dalam jenis almahalliyah [المحلية] (Fayyud, 1998).

\section{9) Hadhf al-mudaf ilayh (Elipsis kata majmuk)}

Firman Allah SWT di dalam al-Quran, daripada Surah al-A'raf, ayat 151 :

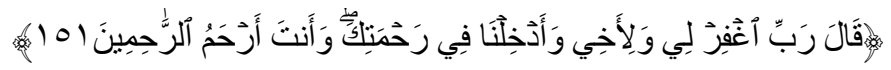

Terjemahan: Nabi Musa berdoa dengan berkata: "Wahai Tuhanku, ampunkanlah bagiku dan bagi saudaraku, dan masukkanlah kami ke dalam rahmat-Mu, kerana Engkaulah sahaja yang Maha Mengasihani daripada segala yang lain yang mengasihani”.

Al-Hadhf yang melibatkan mudaf ilayh pula dapat dijelaskan berdasarkan ayat 151 Surah al-A'raf ini. Menurut al-Mut'aniy (1992), al-hadhf yang melibatkan mudaf ilayh banyak berlaku pada huruf ya' al-mutakallim [ياء المتكلم], iaitu huruf ya' yang merujuk kepada maksud "saya" atau "aku". Contoh perkataan idafah bagi jenis ini ialah [ربي]. Pada kebanyakan tempat dalam ayat al-Quran yang melibatkan perkataan idafah [ربي]., huruf ya' yang kedudukan fleksinya mudaf ilayh digugurkan. Keadaan ini khusus merujuk kepada ayat berbentuk seruan atau [نداء]].

Pada ayat 151 daripada Surah al-A'raf, terdapat perkataan [ب] yang merupakan doa Nabi Musa a.s. kepada Allah SWT (Ibn Kathir ,2004: 2/1156). Perkataan ini termasuk dalam bentuk seruan atau [نداء] dan ia merujuk kepada makna "Tuhanku” atau [ربي]. Perkatan [ربي] merupakan perkataan yang termasuk dalam kategori idafah, iaitu sebagai mudaf dan [ياء المتكلم] sebagai mudaf ilayh. Pengguguran mudaf ilayh pada perkataan idafah diterima dari sudut tatabahasa Arab. 
Sebahagian mufassir menjelaskan, pengguguran mudaf ilayh yang melibatkan ya' al-mutakallim pada perkataan [رب] tidak mengubah makna sepertimana yang dimaksudkan kerana lafaz Tuhan [رب] yang merujuk kepada Allah SWT menjadi makluman semua (al-Mut'aniy, 1992). Pada ayat 151 Surah al-'Araf ini, perkataan [رب] yang digunakan oleh Nabi Musa a.s. ini telah memberi makna yang jelas bahawa ia hanya merujuk kepada Allah SWT dan bukan makhluk lain.

\section{PENUTUP}

Kewujudan elipsis (al-hadhf) merupakan satu keistimewaan bagi alQuran. Berdasarkan pentafsiran para mufassir pada ayat-ayat al-Quran yang terlibat dengan elipsis (al-hadhf), memberi petunjuk jelas bahawa al-Quran diturunkan daripada Allah SWT kepada umat manusia. Hal ini turut menjelaskan bahawa bahasa Arab yang termaktub di dalam al-Quran merupakan bahasa Arab tinggi yang sarat dengan keindahan dan kedalaman makna dan perlu difahami berlandaskan ilmu. Manusia perlu memiliki ilmu untuk memahami wahyu Allah SWT serta menggunakan akal fikiran untuk memanfaatkan khazanah yang terdapat dalam Kalamu'Llah ini. Firman Allah SWT dalam al-Quran yang bermaksud: "Sesungguhnya Kami menurunkan Kitab itu sebagai Quran yang dibaca dengan bahasa Arab, supaya kamu (menggunakan akal untuk) memahaminya" (Surah Yusuf, ayat 2).

Perlu dijelaskan bahawa elipsis atau al-hadhf ini tidak membawa pengertian bahawa al-Quran itu tidak sempurna. Sebaliknya, uslub atau gaya bahasa ini memberi gambaran bahawa al-Quran itu amat istimewa kerana kewujudan elipsis (al-hadhf) pada sesuatu ayat al-Quran membawa pengertian tertentu, yang kemudiannya dikaji dan ditafsir oleh para mufassir. Keadaan ini secara langsung membuktikan bahawa elipsis (al-hadhf) merupakan antara keistimewaan al-Quran dan bukannya kekurangan. Sesungguhnya, telah jelas bagi orang yang beriman bahawa al-Quran merupakan sebuah kitab yang sempurna dan tiada sebarang syak dan keraguan di dalamnya serta ia akan terus kekal terpelihara dalam pemeliharaan Allah SWT. Firman Allah SWT di dalam al-Quran yang bermaksud, "Sesungguhnya Kamilah yang menurunkan al-Quran, dan Kamilah yang memelihara dan menjaganya" (Surah al-Hijr, ayat 9). 


\section{RUJUKAN}

Abdullah Basmeih. (2013). Tafsir pimpinan Ar-Rahman kepada pengertian alQuran (Cet. ke-22). Kuala Lumpur: Darul Fikir.

Abu Shadiy, Mustafa 'Abd al-Salam Muhammad. (1992). al-Hadhf al-balaghiy fi al-Qur'an al-Karim. al-Qahirah: Maktabah al-Qur'an li al-Tab' wa alNashr wa al-Tawzi‘.

Al-Mut'aniy, 'Abd al-'Azim b. Ibrahim. (1992). Khasa'is al-ta 'bir al-Qur'aniy wa simatuh al-balaghiyyah. al-Qahirah: Maktabah Wahbah.

Al-Qur'an al-Karim. Al-Rajihiy, 'Abduh. (1988). al-Tatbiq al-nahwiy. Bayrut: Dar al-Nahdah al-'Arabiyyah li al-Tiba'ah wa al-Nashr.

Al-Sabuniy, Muhammad 'Ali. (1979). Safwah al-tafasir. Al-Qahirah: Dar alSabuniy li al-Tiba'ah wa al-Nashr wa al-Tawzi'.

Al-Samirra'iy, Fadil Salih. (1998). Al-Ta 'bir al-Qur'aniy. 'Amman: Dar 'Ammar.

Fadl Hasan 'Abbas. (2010). Lata'if al-mannan wa rawa 'i al-bayan fi nafy al-ziyadah wa al-hadhffi al-Qur'an. 'Amman: Dar al-Nafa' is li al-Nashr wa al-Tawzi'.

Fayyud, Basyuni 'Abd al-Fattah. (1998). 'Ilm al-bayan: Dirasah tahliliyyah li masa'il al-bayan. al-Qahirah: Mu'assasah al-Mukhtar li al-Nashr wa alTawzi'.

Ibn Hisham, 'Abdullah b. Yusuf. (2000). Awdah al-masalik ila alfiyah Ibn Malik. Bayrut: Dar al-Fikr.

Ibn Kathir, 'Imad al-Din Abi al-Fida' Isma'il b. 'Umar b. Kathir. (2004). Tafsir al-Qur' an al- 'Azim. al-Riyad: Dar al-Salam li al-Nashr wa al-Tawzi'.

Ibn Manzur, Muhammad b. Mukarram b. 'Ali b. Ahmad. (1994). Lisan al-'Arab. Bayrut: Dar al-Fikr.

Kamarul Shukri Mat Teh. (2005). Tatabahasa Arab dan pembinaan hukum daripada al-Quran. Kuala Lumpur: Penerbit Universiti Malaya.

Tammam Hassan. (1994). al-Lughah al-'Arabiyyah: Ma'naha wa mabnaha. alMaghrib: Dar al-Thaqafah. 
